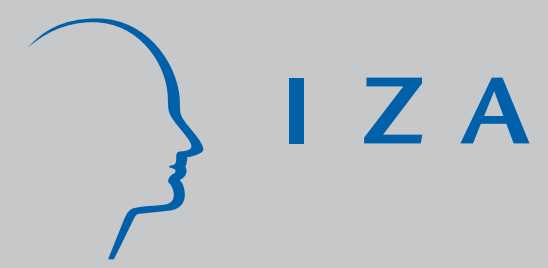

IZA DP No. 5576

The Impact of Amnesty on Labor Market Outcomes: A Panel Study Using the Legalized Population Survey

Catalina Amuedo-Dorantes

Cynthia Bansak

March 2011 


\title{
The Impact of Amnesty on Labor Market Outcomes: A Panel Study Using the Legalized Population Survey
}

\author{
Catalina Amuedo-Dorantes \\ San Diego State University \\ and IZA \\ Cynthia Bansak \\ St. Lawrence University
}

\author{
Discussion Paper No. 5576 \\ March 2011
}

\author{
IZA \\ P.O. Box 7240 \\ 53072 Bonn \\ Germany \\ Phone: +49-228-3894-0 \\ Fax: +49-228-3894-180 \\ E-mail: iza@iza.org
}

Any opinions expressed here are those of the author(s) and not those of IZA. Research published in this series may include views on policy, but the institute itself takes no institutional policy positions.

The Institute for the Study of Labor (IZA) in Bonn is a local and virtual international research center and a place of communication between science, politics and business. IZA is an independent nonprofit organization supported by Deutsche Post Foundation. The center is associated with the University of Bonn and offers a stimulating research environment through its international network, workshops and conferences, data service, project support, research visits and doctoral program. IZA engages in (i) original and internationally competitive research in all fields of labor economics, (ii) development of policy concepts, and (iii) dissemination of research results and concepts to the interested public.

IZA Discussion Papers often represent preliminary work and are circulated to encourage discussion. Citation of such a paper should account for its provisional character. A revised version may be available directly from the author. 
IZA Discussion Paper No. 5576

March 2011

\section{ABSTRACT \\ The Impact of Amnesty on Labor Market Outcomes: A Panel Study Using the Legalized Population Survey}

This paper tests whether amnesty, a provision of the 1986 Immigration Reform and Control Act (IRCA), affected the labor market outcomes of the legalized population. Using the Legalized Population Survey (LPS) and the National Longitudinal Survey of Youth (NLSY79) from 1987-1992, a quasi-experimental framework is developed to assess the differential impact of amnesty on the legalized population relative to a comparison group. After the implementation of the amnesty program, employment fell and unemployment rose for newly legalized men relative to the comparison group of already legal U.S. residents. For women, employment also fell and transitions out of the workforce increased among the newly legalized population. Increasing returns to skill, as captured by English proficiency, only played an important role in explaining the employment of newly legalized women. Finally, newly legalized men and women enjoyed higher wage growth rates than their working native counterparts, perhaps owing to their comparatively growing returns to U.S. educational attainment over this period.

JEL Classification: J6

Keywords: amnesty, legalization, labor market, Legalized Population Survey

Corresponding author:

Catalina Amuedo-Dorantes

Department of Economics

San Diego State University

5500 Campanile Drive

San Diego, CA 92182

USA

E-mail: camuedod@mail.sdsu.edu 


\section{Introduction}

Undocumented immigration has been a long-standing component of the U.S. labor market as most illegal immigrants enter the U.S. in search of work. How to address the current recordhigh number of unauthorized workers within our borders has been the topic of heated debate. Past efforts to moderate inflows by increasing border enforcement, imposing fines on employers, and granting amnesty to long-term undocumented residents can be used to guide future immigration reform. While a number of studies have examined the effect of employer sanctions (Bansak and Raphael 2001, Bansak 2005, Cobb-Clark et al.1995) and border enforcement (Amuedo-Dorantes and Bansak 2007, Orrenius and Zavodny 2003), only a handful have examined the impact of amnesty on the newly legalized (Kassoudji and Cobb-Clark 2002, 2004, Kaushal 2006). Despite recent debates regarding the usage of a generalized or partial amnesty as a means to address current immigration concerns, the impact of past amnesty programs on labor market outcomes post-legalization has not been widely documented and the analysis has been limited to men.

In this paper, we examine whether amnesty, a provision of the 1986 Immigration Reform and Control Act (IRCA), affected the labor market outcomes and wages of the legalized population by gender. The analysis is carried out by gender to address male and female differences in labor supply and earnings. Using the Legalized Population Survey (LPS) and a comparison sample from the 1979 National Longitudinal Survey of Youth (NLYS79), a quasiexperimental framework is developed to assess the differential impact of amnesty on the legalized population relative to a comparison group.

The analysis is of interest as legal status can have a direct effect on employment opportunities (employer-employee matches) if mobility is limited for undocumented workers due to discrimination, fear of apprehension, or low returns to human capital (Calavita 1992). 
Specifically, if undocumented workers feel that they have limited job alternatives, they may exhibit a strong attachment to their employers. Furthermore, this attachment may enhance the monopsonistic power (or bargaining power) of employers who, in turn, would pay wages below the marginal revenue product (Black 1995, Raphael and Riker 1999, Pagan and Davila 1996). As such, legalization could enhance labor market efficiency and raise wages by improving mobility and the quality of job matches (Black 1995, Raphael and Riker 1999).

Our results reveal differences in the labor market outcomes and wages for the newly legalized compared to native workers by gender. To begin, employment rates fell and unemployment rose for the newly legalized male population relative to a comparison group of natives following legalization. Likewise, employment rates fell while transitions out of the workforce increased for newly legalized female immigrants when compared to their Hispanic native counterparts. An examination of the determinants of the labor market status before and after amnesty suggests that increasing returns to English proficiency played an important role in women's labor force status. Specifically, English proficient women were more likely to be employed and less likely to be out of the labor force after amnesty, whereas English proficiency was not a significant determinant for women before legalization. However, returns to skill played a minimal role as determinants of the labor market status of men before and after amnesty. Finally, newly legalized men and women enjoyed higher wage growth rates than their working native counterparts, possibly as a by-product of their comparatively growing returns to U.S. educational attainment over this period. In sum, amnesty may have improved labor market efficiency by increasing transparency, job mobility and the quality of job matches for some, while also reducing the labor market participation of others.

\section{The 1986 Immigration Reform and Control Act (IRCA)}


After an intense fifteen-year debate, IRCA was passed in 1986 and was the first major immigration legislation in over two decades. The intent of IRCA was to stem the flow of increased illegal immigration into the United States. Border apprehensions of illegal immigrants had risen from 250,000 in 1970 to 1.6 million in 1986 and advocates of immigration control expressed concern over problems associated with illegal immigration. Specifically, IRCA adopted three strategies to accomplish its goals: 1) increased INS resources for border enforcement, 2) introduced employer sanctions for knowingly hiring undocumented workers and 3) offered two amnesty programs to legalize illegal resident aliens.

The two amnesty programs together enabled 2.7 million undocumented immigrants to acquire legal permanent resident (LPR) status in the United States. It is estimated that most undocumented migrants applied for legalization (Warren 1995, Hoefer 1991). The process of legalization lasted an average of two years -more than 95 percent of legalizations took place between 1989 and 1991, and had a high rate of success -about 9 out of 10 applicants obtained LPR status (Rytina 2002).

The first and larger program offered amnesty under section 245A of the Immigration and Nationality Act (INA) to 1.6 million illegal aliens who demonstrated continuous residency since January 1, 1982 (nearly 5 years). ${ }^{1} \quad$ The second program, known as the Special Agricultural Worker (SAW) program, was intended to grant amnesty to illegal workers with ties to agriculture. This program granted LPR status to 1.1 million undocumented workers with 90 days of seasonal

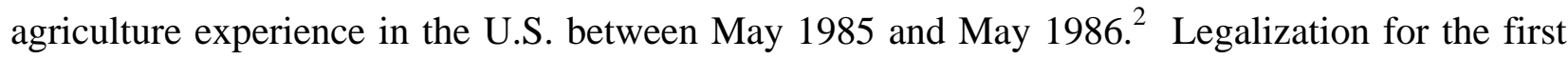

\footnotetext{
${ }^{1}$ Between May 5, 1987 and May 4, 1988, 1.8 million persons applied for amnesty under section 245A; 1.7 million were granted temporary resident alien status and about 1.6 million were ultimately granted lawful permanent resident status (Department of Labor, 1996).

${ }^{2}$ According to Martin and Taylor (1990), program applications for the SAW program were nearly four times the expected number and the SAW program may have attracted new immigration into the United States and increased the immigrant supply of labor.
} 
group - considered long-term illegal residents - was intended to bring undocumented workers "out of the shadows" and improve their wages and working conditions by reducing workplace vulnerabilities (Kassoudji and Cobb-Clark 2002, 2004). This group was followed and surveyed through the longitudinal Legalized Population Survey and the question as to how legalization actually changed their labor market outcomes - as captured by their employment status and wages- is the focus of this paper.

\section{Theoretical Predictions Regarding the Labor Market Impact of the Amnesty}

A number of studies suggest that legalization or naturalization results in better labor market outcomes for immigrants (Kaushal 2006, Bratsburg et al., 2002, Kossoudji and CobbClark 2002, 2004; Rivera-Batiz, 1999). Specifically relevant to our study is the work by Kossoudji and Cobb-Clark (2002), who also work with the LPS and a comparison sample from the NLSY79 to show that following legalization, English proficiency and education enhanced wage growth for male immigrants. As such, they conclude that their results show strong evidence that IRCA's amnesty provisions improved the labor market opportunities of legalized workers. While ground-breaking, their analysis of the impact of IRCA's general amnesty is focused on the determinants of male wages before and after legalization without further consideration to the impact of legalization on their labor force status or on the labor market outcomes of women. In particular, their study does not discuss the fact that English proficiency and educational attainment are characteristics often held by a minority of the legalized population. Consequently, the possibility exists that, while skilled workers with strong ties to the labor market fared better, immigrants with limited skills were more likely to drop out of the labor market or enter the pool of unemployed following their legalization. 
To guide our empirical work, it is helpful to sketch out a simple conceptual framework of the relationships between amnesty, labor force status, and wages. Suppose that legalization is likely to raise the returns to skill and, via greater mobility, raise market wages for legalized immigrants. According to the neoclassical model of labor-leisure choice (Killingsworth 1983), legalization can affect labor supply decisions of immigrants differently depending on their skill level and preferences. A variety of outcomes may then be observed. We explain the factors affecting the labor supply response of immigrants to amnesty below. Specifically, we distinguish three scenarios:

1. $\quad$ Staying employed but earning higher wages (Figure A): Among continuously employed skilled migrants, legalization may simply translate into higher hourly wages. Increased labor market opportunities may induce some of these migrants to either move to better paying jobs or to negotiate a higher pay with the same employers once legalized. By bringing workers 'out of the shadows', legalization may also increase the reservation wage of unskilled migrants previously lacking any bargaining power owing to their undocumented status. If the lack of the appropriate visa status was the cause for the low-paid jobs held by these workers, unskilled workers may also enjoy a wage increase in their same or in new jobs.

2. Exiting employment (Figure B): By raising the returns to skill and by qualifying for unemployment insurance, legalization may raise the reservation wage of skilled workers, who may choose to search longer for a good job match. In that event, newly legalized skilled immigrants may be more likely to be observed exiting employment at a particular point in time than before legalization. Eligibility for unemployment insurance while not working -a source of non-labor income- may create a spike in the budget constraint at zero hours of work, raising reservation wages above their pre-legalization level, which means that a return to work is only 
possible if the worker finds a higher-paying job (Figure B - left panel). As noted by Borjas and Tienda (1993), newly legalized unskilled workers employed in low-paid jobs are more likely to become eligible for public assistance, which may raise their reservation wages. Similar to unemployment insurance, the receipt of social services -another source of non-labor incomemay result in a pure income effect that shifts the budget constraint outward (up to the maximum need-based income level - a kinked budget constraint under AFDC) and reduces the employment likelihood of newly legalized unskilled immigrants (Figure B - right panel). Furthermore, such an income effect could also be explained by the existence of families who previously had dual earners. Spouses' higher labor income may raise the reservation wages of secondary household earners and induce them to step out of the labor market.

3. Entering employment (Figure C): Higher wages resulting from legalization and the opening of new job opportunities may also induce some previously non-working immigrants to become employed. Specifically, an increase in market wages would raise the slope of the budget constraint, which in turn would attract some individuals with steep indifference curves into work.

Predictions: While the overall flow into and out of employment is an empirical question, the number of newly legalized immigrants exiting non-employment and entering into employment is likely to be small since undocumented immigrants typically have higher employment rates than their documented counterparts or natives (Borjas and Tienda 1993). Therefore, the flows out of employment are likely to be larger than the flows into employment. Additionally, the reasons behind the observed employment outflows may differ by skill level and gender. Given the comparatively higher skill level of immigrant men relative to women, ${ }^{3}$ we would expect a higher fraction of men to be leaving their employers in search for a better job -perhaps while receiving 
unemployment insurance, whereas a larger percentage of newly legalized immigrant women would be exiting the workforce and qualifying for public assistance. ${ }^{4}$ Finally, for men and women employed pre and post legalization, the theory predicts an increase in wages as a byproduct of the higher mobility and returns to their skills following legalization.

\section{Data}

This paper uses data from two longitudinal surveys in order to examine the impact of legalization under IRCA's main amnesty program on the employment outcomes and wages of newly legalized immigrants while controlling for macroeconomic conditions in a quasiexperimental design that largely follows that of Cobb-Clark and Kassoudji (2002). Authorized by Congress, the Legalized Population Survey (LPS) is the only nationally representative dataset designed to analyze the impact of IRCA's main amnesty program on the legalized population. Participants were randomly selected and interviewed in 1989 and two-thirds were interviewed again in 1992 after most had spent more than a decade of continuous residency in the United States. The first survey (LPS1) collected information from 6,193 individuals who had applied for temporary residence status by January 31, 1989. In this survey, respondents were asked to describe their employment status in the week before the amnesty application was filed. In the follow-up survey (LPS2), approximately 4 years later, about 4,012 LPS1 respondents who were granted lawful permanent residence by 1992 were re-interviewed. ${ }^{5}$ These two surveys together

\footnotetext{
${ }^{3}$ On average, men in the LPS have 8.4 years of education, 7.3 years of work experience and 51 percent of them are proficient in English. In contrast, their female counterparts have, on average, 8.1 years of education, 6.9 years of work experience and only 40 percent of them can read and speak English fluently.

${ }^{4}$ Indeed, authors' tabulations using the LPS2 data show that that a higher percentage of newly legalized immigrant women receive school lunches, food donations, Aid for Families with Dependent Children, child support and food stamps compared to their male counterparts. However, a higher percentage of newly legalized immigrant men receive unemployment insurance and workers compensation than as compared to newly legalized immigrant women. ${ }^{5}$ Only 2/3rds of the LPS1 sample was re-interviewed in the LPS2 for several reasons. The LPS2 excluded those who those whose age or immigration status disqualified them from the earlier survey, as well as LPS1-

eligibles who had died, permanently left the contiguous 48 states, or failed to receive lawful permanent residence by
} 
form the longitudinal LPS panel, which we utilize for this study. It should be noted that the LPS is not representative of all amnesty recipients, but of long-term illegal aliens who were able to document continuous unauthorized residency in the U.S. since 1982 and who were able to successfully take advantage of IRCA's main amnesty program to adjust their legal status. Nonetheless, the longitudinal nature of the dataset makes it highly valuable when examining the potential impact of legalization on the employment outcomes of affected immigrants as it tracks respondents over the period surrounding their change in legal status.

To investigate whether IRCA affected the labor market outcomes and wages of those who became legalized due to the amnesty provisions, we chose a comparison group similar to the target group but unaffected by the amnesty program. The ideal comparison group would consist of a randomly selected group of undocumented immigrants similar to the target group, but ineligible for, and unaffected by, the generalized amnesty. However, this is not possible due to the fact that IRCA was a broad-based legislation that affected undocumented immigrants who obtained legal status as well as those who did not (e.g. Bean et al. 1988, Bansak and Raphael 2001). Therefore, following Kossoudji and Cobb-Clark (2002), we work with a sample of Hispanic natives from the 1979 National Survey of Youth (NLSY79) of similar age and work experience. $^{6}$ While the labor market determinants of undocumented immigrants are likely to differ from those of natives, the use of panel data allows us to compare difference-in-differences and take into account divergences between these two groups at any point in time. ${ }^{7}$ The NLSY79 is a nationally representative sample of 12,686 civilian young men and women aged 14-21 as of

\footnotetext{
January 1992. Furthermore, an additional 691 LPS1 respondents were excluded due to resource limitations and these individuals were randomly selected for exclusion. (http://mmp.opr.princeton.edu/LPS/LPSreadme.pdf).

${ }^{6}$ We restrict our sample to only natives due to the lack of information on the legal status of immigrants in the NLSY79.

${ }^{7}$ Furthermore, Bailey (2002) finds that the effect of amnesty on natives is not likely to be significant.
} 
December 31, 1978. This cohort was interviewed annually from 1979 through $1994 .^{8}$ We work with a sample of 1,200 Hispanic natives from the 1987 and 1992 rounds of the NLSY79 of similar age, family size, and work experience.

Using both surveys, we compare by gender the labor market outcomes before and after the legalization of the LPS sample to those of an already legal population of similar ethnicity, age, and labor market experience in the NLSY79. The usage of a comparison sample allows us to separate the impact of business and life-cycle effects concurrent with IRCA's amnesty program that may have affected the observed employment and unemployment outcomes of legalized immigrants. Notably, the economy experienced a recession between July 1990 and March 1991 which worsened employment prospects for those in both surveys.

Table $\mathrm{A}$ in the appendix provides a description of the variables used in our analysis. A number of variables are only relevant for the LPS sample, such as U.S. education or English proficiency since both equal 1 for all respondents in the NLSY79 sample. Table B and Table C further show the male and female sample means in the LPS and NLSY79 samples before and after legalization, i.e. in 1987 and in 1992. An initial comparison of the LPS and NLSY79 respondents reveals a number of similarities. Because of the sample restrictions, respondents in the LPS and NLSY79 are close in age, family size (which fluctuates between 3 and 4 members in 1987) and display similar years of work experience (i.e. between 7 and 7.5 years of experience in 1987) before the legalization of the LPS sample. Additionally, more than half of all respondents in both samples of men and women are of Mexican origin. Lastly, both samples are geographically concentrated in the West (largest share for both samples) and South with a minority residing in the North East and North Central regions of the United States.

\footnotetext{
${ }^{8}$ Starting in 1994, the interviews were conducted biennially.
} 
Among working respondents, the LPS sample earns somewhat less than the NSLY79 sample, although both earn relatively low real wages (between \$6 and \$9 in 1992 dollars). Likewise, both LPS men and their Hispanic counterparts in the NLSY79 are relatively concentrated in manufacturing, trade and construction. However, the industry of working LPS women and Hispanic women in the NLSY79 show greater differences. Specifically, LPS women work predominantly in manufacturing, personal services and trade, whereas Hispanic women in the NLSY79 are primarily employed in professional related services, finance, insurance, real estate and manufacturing. These figures suggest that, owing to the often informal nature of personal service employment, especially newly legalized women may be less likely to qualify for unemployment insurance than their Hispanic NLSY79 counterparts.

\section{Empirical Methodology}

\subsection{The Impact of IRCA on the Labor Force Status of the Legalized Population}

The objective of our study is to examine the impact of IRCA's main amnesty program on the economic well-being of its beneficiaries as captured by changes in their labor market status and wages. With that purpose in mind, we use a difference-in-difference approach that relies on the usage on the identification of a target group -in our case newly legalized immigrants in the LPS- and a comparison group from the NLSY79. Assuming that unmeasured factors contemporaneous to IRCA have the same impact on the labor market outcomes of the legalized population (LPS) and Hispanic population from the NLSY79, an estimate of the relative labor market effects of IRCA's main amnesty program is given by:

$$
\Delta_{\text {Amnesty }}^{2}=\left(L_{\text {Legalized }}^{A}-L_{\text {Legalized }}^{B}\right)-\left(L_{\text {Legal }}^{A}-L_{\text {Legal }}^{B}\right)
$$

where $L_{j}{ }_{j}$, is the labor market outcome for group $j$ in time period $i$ (A = post-legalization or 1992, $\mathrm{B}=$ pre-legalization or 1987). 
The double difference estimate in equation (1) is based on the assumption that workers in the LPS and NLSY79 are similar (aside from differing in their initial legal status). However, it may be possible that these two groups of workers vary in some respects. For example, educational attainment and other background characteristics may differ across these two groups. An alternative estimate that adjusts for differences in observable and unobservable individual level characteristics can be derived from the following regression equation for the pooled sample of legalized and already legal workers:

$$
P\left(L_{i t}=1\right)=\Phi\left(\beta_{0}+\beta_{1} L P S_{i}+\beta_{2} \text { Post } 87_{t}+\beta_{3} \text { LPS }_{i} *{\text { Post } 87_{t}}_{t} \beta_{4}^{\prime} X_{i t}\right)
$$

where $\Phi$ stands for the normal cumulative density function. The $i$ indexes individuals and $t$ indexes time; equation (2) was estimated as a pooled probit model with clustering at the individual level. ${ }^{9} \quad L$ represents the labor market outcome in question, LPS is a dummy variable indicating that the worker belongs to the LPS sample and Post87 is a dummy variable indicating that the observation corresponds to the post-legalization period. The marginal effect of the interaction term gives the extent to which labor market outcomes for legalized workers differs from the comparable change experienced by legal workers before and after legalization and after controlling for observable personal characteristics included in $X$. Additionally, the vector $X$ includes interaction terms between the Post87 dummy and education and experience to allow for changes over time in the returns to education and experience (Freeman and Katz 1994). As a result, the estimate from the LPS* Post87 interaction term is directly comparable to the unadjusted double-difference in equation (1), with the advantage that it also accounts for observed and unobserved individual level characteristics.

\footnotetext{
${ }^{9}$ We also estimated equation (2) as a random-effects probit and a fixed-effects logit. While the results from the probit were qualitatively similar and are available upon request, the fixed-effects logit dropped variables of key interest, such as $L P S_{i t}$ and Post87 it
} 
The preceding analysis tells us about the potential impact of legalization on the labor market outcomes of legalized immigrants. However, it does not reveal the factors driving such an impact. One way to understand the determinants of amnesty's effect on the labor market outcomes of the newly legalized is to estimate the probability of being in a labor market state before and after amnesty for each group of men and women and then compare changes in the coefficients of key determinants of respondents' labor force status. With that purpose, we estimate probit models of the likelihood of being employed, unemployed or not in the labor force separately by gender, group (LPS and NLSY79), and year (1987 and 1992) to then focus on the potential for changes in return to skills -as captured by English proficiency, any U.S. education, schooling and years of work experience- over this period of time.

\subsection{The Impact of IRCA on the Wage Growth of the Legalized Population}

As reflected by Figures B and C in the appendix, legalization may have affected the labor force status held by newly legalized immigrants. This is true if legalization raised the returns to skill and induced some legalized immigrants to step into the workforce (Figure C). Alternatively, higher reservation wages following qualification for social services and unemployment insurance may have motivated some working migrants to search for better job opportunities or to step out of the workforce (Figure B). However, the possibility also exists that some immigrants may have remained employed in both periods and may have seen a change in their wages (Figure A). In an earlier study, Kossoudji and Cobb-Clark (2002) examine the impact of legalization on the wages earned by immigrants in the LPS. They estimate wage regressions in different time periods using a working sample from the LPS and a comparison sample from the NLSY79. After examining the role played by wage determinants over time, they conclude that wage determinants changed after amnesty for the legalized population but not for the comparison group. Nevertheless, 
because they do not exploit the longitudinal nature of the LPS, their analysis cannot gauge the impact of amnesty on individual wage growth. Furthermore, their focus is on working men. We thus expand their analysis using separate panels of employed men and women. We first estimate the relative wage impact of IRCA's main amnesty program by computing:

$$
\Delta_{\text {Amnesty }}^{2}=\left(w_{\text {Legalized }}^{A}-w_{\text {Legalized }}^{B}\right)-\left(w_{\text {Legal }}^{A}-w_{\text {Legal }}^{B}\right)
$$

where $\mathrm{w}_{j}{ }^{i}$ is the log hourly wage earned by respondents in each of the two samples pre and post legalization of the LPS.

To account for individual level characteristics, we also estimated the expected wage growth experienced by immigrant and native men and women as:

$$
E\left[\left(\ln \text { wages }_{i, t=2}-\ln \text { wages }_{i, t=1}\right) \mid \text { Employed 87,92 }_{i}\right]=\theta^{\prime} Z_{i, t=2}+\xi L P S_{i}+v_{i}
$$

where the vector $Z$ includes the respondents' personal characteristics used in modeling their labor force statuses (i.e. the vector $X$ in equation (2)), as well as information on the industry where respondents were employed. ${ }^{10}$

As with the previous analysis of changes in labor force status, we also examine the determinants of changes in wage growth for the LPS and the Hispanic NLSY79 samples before and after legalization of the LPS group. To that end, we estimate models of the log real hourly wages earned by men and women in the LPS and NLSY79 samples in 1987 and in 1992, conditional on being employed in both periods. We then track changes in the coefficients of male and female respondents' skill proxies within each sample to assess the role of returns to skill as

\footnotetext{
${ }^{10}$ We also estimated a Heckman selection type model where we examine the wage growth experienced by the legalized population relative to their legal counterparts while accounting for the ongoing selection into employment. Because the results were similar and the Heckman model involves identification restrictions, we report the results using the simpler OLS specification. However, results using the Heckman model are available from the authors upon request.
} 
determinants of the wage growth experienced by LPS men and women before and after legalization.

\section{Empirical Results}

\subsection{The Impact of IRCA on the Labor Force Status of the Legalized Population}

Table 1 presents unadjusted estimates of the amnesty effect on the legalized population in the period surrounding the implementation of IRCA. For the years 1987 (pre-IRCA) and 1992 (post-IRCA), tabulations are presented for three separate labor market outcomes according to whether the individual is in the legalized sample (LPS) or in the already legal sample (NLSY79). Recall that this approach provides us with the difference-in-difference estimator of the "amnesty effect” described in equation (1).

According to the figures in Panel A and D from Table 1, the passage of IRCA was followed by statistically significant 6.7 and 7.9 percentage point reductions in the share of employed male and female immigrants, respectively. By contrast, the employment rate of men and women in the NLSY79 sample remained stable between 1987 and 1992 (dropping by 2.1 percentage points and falling by half a percentage point, correspondingly). Across the target and control groups, the relative decline in employment turns out to be statistically significant at the 10 percent level for both men and women, for whom the difference-in-difference estimate is 4.6 and 7.4 percentage points, respectively. As such, it appears that amnesty resulted in a fall in employment for the legalized population relative to their already legal counterparts.

Regarding unemployment, shown in Panel B and Panel E from Table 1, changes and relative changes are only significant for men. The share of unemployed rose by 5 percentage points for male immigrants and by 2.4 percentage points for native men over the time period under consideration. For women, these increases were 2.2 and 1.4 percentage points, 
respectively. Since the difference in unemployment rates pre and post between the LPS and the NLSY79 samples is greater for men (2.6 versus 0.8 percentage points), it is not surprising that the difference-in-difference estimate is significant only for men. That is, unemployment increased by 2.6 percentage points more for the male LPS sample following legalization relative to the male NLSY79 sample.

Lastly, the figures in Panels $\mathrm{C}$ and $\mathrm{F}$ reveal changes and relative changes in the share of the legalized population dropping out of the workforce. The share of the male legalized population dropping out of the workforce increased for both LPS and Hispanic men in the NLSY79. Therefore, the difference-in-difference estimate does not turn out to be significantly different from zero for men. The share of women "not in the labor force" rose by 5.7 percentage points for the LPS sample, while it declined by 0.9 percentage points among Hispanic natives. As such, we find that the difference-in-difference estimator is positive and significant. In particular, the share of legalized women dropping out of the workforce grew by 6.6 percentage points relative to their already legal counterpart over the period surrounding the implementation of IRCA’s amnesty provisions.

Altogether, the figures from Table 1 suggest that the amnesty program seems to have reduced employment and raised unemployment rates among the newly-legalized male population. For women, amnesty resulted in a lower employment rate and a greater propensity to be out of the labor force. Nonetheless, these results assume that immigrants in the LPS sample and their native counterparts in the NLSY79 are similar with respect to a myriad of personal characteristics. Therefore, we next estimate equation (2) for each of the three labor market outcomes in consideration to assess whether the amnesty effects are still observed after we account for individual observable and unobservable characteristics. Additionally, equation (2) includes 
interaction terms between education, experience and the dummy variable indicating a postlegalization observation to allow for changes over time in the returns to education and experience.

Tables 2A and 2B present the coefficients and marginal effects from the probit models estimated for each of the labor market outcomes being examined for men and women, correspondingly. Starting with the figures in Table 2A, the coefficients on the LPS term suggest that the legalized male population is more likely than their already legal counterparts to be employed and less likely to be unemployed or out of the workforce in the pre-legalization period (1987). This result is not surprising as the labor force participation rate is typically high and unemployment low for undocumented immigrants since an improved labor market experience is the predominant reason for migration decisions (Borjas and Tienda 1993). Therefore, just as suggested by the figures in Table 1 , the amnesty program appears to have reduced the employment likelihood of legalized male immigrants by 6.1 percentage points while also raising their unemployment likelihood by 5.7 percentage points.

Turning to women, the figures in Table 2B reveal that the legalized female population is more likely than their already legal counterparts to be employed and less likely to be unemployed or out of the workforce in the pre-period. However, once we account for individual observed and unobserved characteristics, control for the experiences of native women, as well as for changing returns to education and experience over the period under consideration, the amnesty program seems to have reduced the employment likelihood of legalized women by 10.7 percentage points and raised their likelihood of stepping out of the workforce by 8.0 percentage points.

Overall, the figures in Tables 1 through 2B provide insight into the likely impact that legalization may have had on the employment outcomes of the newly legalized immigrant 
population relative to those of their already legal counterparts. However, they do not show direct evidence of changing returns to skill as motivated by our conceptual framework.

In order to explore the possibilities of changing returns to skill, we estimate probit models of the likelihood of being employed, unemployed, or not in the labor force separately by gender, group (LPS or NLSY79), and year. What can explain who is more likely to be employed, unemployed, and not in the labor force before and after IRCA's amnesty provisions were implemented? We first address this question for women. As shown in Table 3B, LPS women enjoyed small returns to their educational attainment before legalization, whereas their Hispanic native counterparts experienced sizable benefits to additional schooling. For each year of schooling, LPS women were 1.2 percentage points more likely to be employed, whereas their NLSY79 counterparts experienced a 3.7 percentage point higher probability of being employed for each year of education.

Following their legalization, LPS women became highly rewarded employment-wise for the ability to speak English. Specifically, immigrant women proficient in English were about 10 percentage points more likely to be employed and 11 percentage points less likely to be out of the labor force than their counterparts lacking those English skills. Thus, legalization appears to have reinforced the work attachment of English proficient female workers. Native Hispanic women, however, enjoyed increased returns to educational attainment and work experience. Therefore, as often noted in the migration literature, education and experience are clear signs of human capital for natives, but not for their immigrant counterparts.

As their female counterparts, native Hispanic men enjoyed increasing returns to their educational attainment over the 1987-1992 period (see Table 3A). However, skill (as captured by education, experience or English proficiency) has no explanatory power in predicting the 
employment status of immigrant men before or after their legalization. This finding further corroborates the fact that education and work experience are rewarded differently for natives and immigrants. It is interesting that English proficiency is not as important in explaining the employment of men as compared to women, which may be due to a variety of factors. In particular, immigrant men are more likely to be at work than immigrant women. As such, English proficiency may not play as much of a crucial role in explaining male (relative to female) employment. Additionally, immigrant women are more likely than their immigrant male counterparts to occupy service sector jobs, i.e. personal service industry, where English proficiency may be highly valued.

\subsection{The Impact of IRCA on the Wage Growth of the Legalized Population}

As depicted in Figure A, legalization may not have affected the employment status of some migrants. Yet, these individuals may have still seen an improvement in earnings and experienced a move to a higher indifference curve. To examine the validity of this hypothesis, we first compute a difference-in-difference estimate of the wage growth in the legalized and already legal samples between 1987 and 1992 in Table 4. According to these preliminary estimates, male and female hourly wages of the legalized population sample grew by a statistically significant 6.7 and 10.0 percent, respectively, during the period under consideration. In contrast, the hourly wages of male and female natives seem to have grown from 1987 to 1992 by a non-statistically different from zero 4.2 and 4.8 percent, respectively. Yet, the difference-in-difference estimates or relative increases in hourly wages are not statistically significant for either men or women.

While informative, the figures in Table 4 fail to account for a wide variety of individual level characteristics possibly affecting workers' earnings. Therefore, in Table 5, we display the results from estimating models of wage growth experienced by male and female LPS and 
NLSY79 workers employed in 1987 and in 1992. Did men and women in the LPS sample enjoy a greater wage growth than their comparison counterparts post legalization? According to the estimates in Table 5, wages grew 10.4 percent more for the LPS male respondents than for their male counterparts in the NLSY79 between 1987 and 1992. This figure implies an annualized growth rate of approximately 2 percent. Among women, this growth rate averaged 18.9 percent or about 4 percent per year. Consequently, the figures from Table 5 substantiate the transition depicted in Figure A, suggesting that immigrants employed both pre and post legalization improved their well-being by reaching higher indifference curves.

What factors may lay behind the greater relative wage growth experienced by the LPS men and women? To address this question, Table 6 presents the coefficients on the skill variables (English proficiency, U.S. education, years of education, and years of experience) from log wage models for men and women before and after amnesty was implemented. After legalization, our results suggest that LPS men and women were more highly compensated for their educational attainment. However, language proficiency lost value after legalization. Since the vast majority of continuously employed immigrants in our sample entered the U.S. around the same time, English proficiency -a by-product of the duration of their migration spells- is likely to display limited variability and, consequently, play a lesser role in explaining differences in wage growth. Alternatively, English proficiency may already help explain their employment (as in the case of LPS women following legalization in Table 3B), limiting the importance of language in its role of explaining wage growth. Finally, it is worth noting that while the returns to work experience appeared to have increased for LPS men, they remained non-statistically different from zero for their female counterparts.

In the meantime, work experience lost value and the returns to schooling slightly declined 
among Hispanic native men and women between 1987 and 1992. As such, while LPS men and women enjoyed increasing returns to their educational attainment after legalization, their Hispanic native counterparts appear to have experienced a slight decrease in their rewards to additional schooling. Likewise, while LPS men were enjoying increasing returns to their work experience after legalization, the returns to work experience seemed to vanish for their Hispanic native counterparts by 1992 .

\section{Summary and Conclusions}

Undocumented immigration continues to be the focus of heated debate and amnesty remains as one of the policy options to reduce the large number of unauthorized immigrants in the U.S. How would such a policy affect the labor market outcomes of undocumented immigrants? Would legalized migrants face an easier time coming 'out of the shadows', resulting in greater job mobility? Does legalization raise reservation wages (via a higher return to skill for skilled workers or via eligibility for public services for unskilled workers) and result in lower labor market participation? Which factors are more likely to be driving these trends? Finally, does legalization raise the wages earned by immigrants employed after legalization occurred?

We address these questions with an analysis of the impact that amnesty, a provision of the 1986 Immigration Reform and Control Act (IRCA), had on the labor market outcomes and wages of the legalized population. We use data from the Legalized Population Survey (LPS) and the National Longitudinal Survey of Youth (NLSY79) from 1987-1992 to develop a quasiexperimental framework to assess the differential impact of amnesty on the legalized population relative to a comparison group of U.S. natives. After taking into account any individual level heterogeneity, we find that employment rates fell and unemployment rates rose for the immigrant male population relative to the comparison group post legalization. Among women, legalization 
appears to have reduced employment rates and increased transitions out of the workforce as compared to similar natives. As such, legalization seems to have diminished the employment, unemployment, and out-of-the-workforce disparities between undocumented immigrants and similar U.S. natives. Furthermore, legalization likely enhanced the wage growth of newly legalized men and women.

Our findings also suggest that legalization had a differential impact on the labor supply decisions and wages of immigrants according to their skill level and gender. Legalization seems to have raised the employment-returns to English proficiency, as the work attachment of English proficient women strengthened. Additionally, women in the LPS enjoyed increasing returns to their educational attainment after legalization, while their native Hispanic counterparts experienced a slight decline in the returns to additional years of schooling. Among men, we find that skill variables do not help explain the employment status of immigrant men before or after legalization. Yet, as their female counterparts, newly legalized men were better compensated for their educational attainment, while the wage returns to educational attainment among native Hispanic men declined in the post-IRCA period. Furthermore, newly legalized men enjoyed a higher return to their work experience after legalization, while the returns to work experience previously enjoyed by their Hispanic native counterparts disappeared by 1992.

In sum, although available data do not permit us to eliminate competing explanations entirely, our results suggest that the well-being of skilled immigrants may have improved via greater employment attachment among English proficient women and higher wages for employed men and women -possibly owing to a higher return to their educational attainment and, in the case of men, to their work experience. ${ }^{11} \quad$ For the less skilled, increased eligibility for social

\footnotetext{
${ }^{11}$ In this regard, Powers et al. (1998) document how most unauthorized immigrants found better jobs post IRCA than the ones they had secured upon arrival to the country.
} 
services may have resulted in a reduction in labor force participation. Indeed, while we are unable to assess changes in the usage of public services using the LPS, we find partial evidence of these transitions. Among men, transitions into unemployment increased post-legalization, perhaps owing to their new eligibility for unemployment insurance. Likewise, transitions out of the workforce increased among female immigrants less proficient in English more likely to qualify for public services. Overall, amnesty may have improved labor market efficiency by increasing transparency, job mobility and the quality of job matches for some, while also reducing labor market participation of others. 


\section{References}

Amuedo-Dorantes, Catalina and Cynthia Bansak. 2007. "The Effectiveness of Border Enforcement in Deterring and Postponing Repetitive Illegal Crossings Attempts” Unpublished Manuscript.

Bailey, Linda. 2002. "Did the Immigration Reform and Control Act Affect Relative Labor Market Outcomes?” Unpublished manuscript.

Bansak, Cynthia and Steven Raphael. 2001. "Immigration Reform and the Earnings of Latino Workers: Do Employer Sanctions Cause Discrimination?” Industrial and Labor Relations Review, 54(2): 275-295.

Bean, Frank D., B. Lindsay Lowell, Lowell J. Taylor. 1988. "Undocumented Mexican Immigrants and the Earnings of Other Workers in the United States.” Demography, 25(1): 35-52.

Black, Dan A. 1995. "Discrimination in an Equilibrium Search Model." Journal of Labor Economics, 13(2): 309-324.

Borjas, George and Marta Tienda. 1993. “The Employment and Wages of Legalized Immigrants.” International Migration Review 27(4): 712-747.

Bratsberg, Bernt, Ragan, James and Zafar Nasir. 2002. "The Effect of Naturalization on Wage Growth: A Panel Study of Young Male Immigrants.” Journal of Labor Economics, 20 (3): 568-597.

Cobb-Clark, Deborah, Clinton R. Shiells, and B. Lindsay Lowell. 1995. "Immigration Reform: The Effects of Employer Sanctions and Legalization on Wages." Journal of Labor Economics, 3(3): 472-498.

Davila, Alberto, Jose Pagan and Montserrat Grau. 1998. "The Impact of IRCA on the Job Opportunities and Earnings of Mexican-American and Hispanic-American Workers." International Migration Review, 32(1):80-95.

Davila, Alberto and Jose Pagan. 1997. “The Effect of Selective INS Monitoring Strategies on the Industrial Employment Choice and Earnings of Recent Immigrants.” Economic Inquiry, 35 (1): 138-150.

Department of Labor, Bureau of International Labor Affairs. 1996. "Effects of the Immigration Reform and Control Act: Characteristics and Labor Market Behavior of the Legalized Population Five Years Following Legalization”.

Donato, Katherine M., Durand, Jorge and Douglas S. Massey. 1992. "Changing Conditions in the U.S. Labor Market: Effects of the Immigration Reform and Control Act of 1986." Population Research and Policy Review, 11: 93-115. 
Freeman, Richard B. and Lawrence F. Katz. 1994. "Rising Wage Inequality: The United states vs. Other Advance Countries.” In Richard B. Freeman, ed. Working under Different rules. New York: Russell Sage Foundation, pp. 29-62. .

Hoefer, Michael D. 1991. "Background of U.S. Immigration Policy Reform”, in U.S. Immigration Policy Reform in the 1980s: A Preliminary Assessment, edited by Francisco L. Rivera-Batiz, S. L. Sechzer, and I. N. Gang. New York: Praeger; pp. 17-44.

Kaushal, Neeraj. 2006. “Amnesty Programs and the Labor Market Outcomes of Undocumented Workers.” The Journal of Human Resources, 16(3): 631-647.

Killingsworth, Mark R. 1983. Labor Supply, Cambridge: Cambridge University Press.

Kossoudji, Sherri A. and Deborah A. Cobb-Clark. 1996. "Coming Out of the Shadows: Learning About Legal Status and Wages.” Center for Economic Policy Research Discussion, Paper No. 347.

Kossoudji, Sherrie A. and Deborah A. Cobb-Clark. 2002. "Coming Out of the Shadows: Learning about Legal Status and Wages from the Legalized Population.” Journal of Labor Economics, 20(3): 598-628.

Kossoudji, Sherrie A. and Deborah A. Cobb-Clark. 2004. "IRCA's Impact on the Occupational Concentration and Mobility of Newly-Legalized Mexican Men.” Published in How labor migrants fare, Population Economics series. Heidelberg and New York: Springer, pp. 33350 .

Martin, Philip L. and J. Edward Taylor. 1990. "The Initial Effects of Immigration Reform on Farm Labor in California.” Population Research and Policy Review, 9: 255-283.

Orrenius, Pia and Madeline Zavodny. 2003. “Do Amnesty Programs Reduce Undocumented Immigration? Evidence from IRCA.” Demography, 40(3): 437-450.

Pagan, Jose and Alberto Davila. 1996. "On-the-Job Training, Immigration Reform, and the True Wages of Native Male Workers.” Industrial Relations, 35(1): 45-58.

Powers, Mary G., William Seltzer and Jing Shi. 1998. "Gender Differences in the Occupational Status of Undocumented Immigrants in the United States: Experience Before and After Legalization.” International Migration Review, 32(4): 1015-1046.

Raphael, Steven and David A. Riker. 1999. "Geographic Mobility, Race, and Wage Differentials.” Journal of Urban Economics, 45(1): 17-46.

Rivera-Batiz, Francisco L. 1999. "Undocumented Workers in the Labor Market: An Analysis of the Earnings of Legal and Illegal Mexican Immigrants in the United States.” Journal of Population Economics, 12 (1): 91-116. 
Rytina, Nancy. 2002. "IRCA Legalization Effects: Lawful Permanent Residence and Naturalization through 2001”. Working Paper. Office of Policy and Planning, Statistics Division, U.S. Immigration and Naturalization Service.

Warren, Robert. 1995. "Estimates of the Undocumented Immigrant Population Residing in the United States by Country of Origin and State of Residence: October 1992.” Unpublished. U.S. Immigration and Naturalization Service 


\begin{tabular}{|c|c|c|c|}
\hline & & & \\
\hline Panel A: Em & & & \\
\hline & 1987 & 1992 & $\Delta$ (1992-1987) \\
\hline LPS & $0.961(0.193)$ & $0.894(0.308)$ & $-0.067(0.013)^{* * * *}$ \\
\hline NLSY & $0.871(0.336)$ & $0.846(0.361)$ & $-0.021(0.021)$ \\
\hline Diff-in-diff & - & - & $-0.046(0.024)^{*}$ \\
\hline Panel B: Un & & & \\
\hline & 1987 & 1992 & $\Delta$ (1992-1987) \\
\hline LPS & $0.014(0.120)$ & $0.065(0.246)$ & $0.050(0.010)^{* * *}$ \\
\hline NLSY & $0.056(0.229)$ & $0.079(0.271)$ & $0.024(0.015)$ \\
\hline Diff-in-diff & - & - & $0.026(0.018)^{*}$ \\
\hline Panel C: No & & & \\
\hline & 1987 & 1992 & $\Delta(1992-1987)$ \\
\hline LPS & $0.024(0.154)$ & $0.041(0.199)$ & $0.017(0.009)^{*}$ \\
\hline NLSY & $0.074(0.261)$ & $0.074(0.263)$ & $0.001(0.015)$ \\
\hline Diff-in-diff & - & - & $0.016(0.018)$ \\
\hline & & & \\
\hline Panel D: Em & & & \\
\hline & 1987 & 1992 & $\Delta(1992-1987)$ \\
\hline LPS & $0.735(0.442)$ & $0.656(0.475)$ & $-0.079(0.027)^{* * *}$ \\
\hline NLSY & $0.687(0.464)$ & $0.682(0.466)$ & $-0.005(0.027)$ \\
\hline Diff-in-diff & - & - & $-0.074(0.038)$ \\
\hline Panel E: Un & & & \\
\hline & 1987 & 1992 & $\Delta(1992-1987)$ \\
\hline LPS & $0.035(0.185)$ & $0.057(0.232)$ & $0.022(0.013)$ \\
\hline NLSY & $0.056(0.231)$ & $0.070(0.256)$ & $0.014(0.014)$ \\
\hline Diff-in-diff & - & - & $0.008(0.020)$ \\
\hline Panel F: No & & & \\
\hline & 1987 & 1992 & $\Delta(1992-1987)$ \\
\hline LPS & $0.229(0.421)$ & $0.287(0.453)$ & $0.057(0.026)$ \\
\hline NLSY & $0.256(0.437)$ & $0.247(0.432)$ & $-0.009(0.025)$ \\
\hline Diff-in-diff & - & - & $0.066(0.036)^{*}$ \\
\hline
\end{tabular}

Notes: Standard errors are in parentheses. ${ }^{* * *}$ Signifies statistically different from zero at the 1 percent level or better, ${ }^{* *}$ signifies statistically different from zero at the 5 percent level or better and *signifies statistically different from zero at the 10 percent level or better. 


\begin{tabular}{|c|c|c|c|c|c|c|c|c|c|}
\hline \multicolumn{10}{|c|}{$\begin{array}{l}\text { Table 2A } \\
\text { Probit Estimates of the Effect of Legalization on Male Labor Market Outcomes }\end{array}$} \\
\hline \multirow{2}{*}{$\begin{array}{l}\text { Dependent Variable } \\
\text { Independent Variables } \\
\end{array}$} & \multicolumn{3}{|c|}{ Employed } & \multicolumn{3}{|c|}{ Unemployed } & \multicolumn{3}{|c|}{ Not in the Labor Force } \\
\hline & Coeff. & S.E. & M.E. & Coeff. & S.E. & M.E. & Coeff. & S.E. & M.E. \\
\hline Age & -0.013 & 0.018 & -0.002 & -0.007 & 0.022 & -0.001 & 0.028 & 0.023 & 0.002 \\
\hline Married & $0.464 * * *$ & 0.080 & 0.078 & $-0.347 * * *$ & 0.095 & -0.032 & $-0.434 * * *$ & 0.095 & -0.042 \\
\hline Family Size & $-0.061 * * *$ & 0.017 & -0.009 & 0.031 & 0.021 & 0.003 & $0.071 * * *$ & 0.021 & 0.006 \\
\hline Mexican & -0.079 & 0.086 & -0.012 & $0.230 * *$ & 0.104 & 0.019 & -0.083 & 0.104 & -0.007 \\
\hline U.S. Education & 0.181 & 0.154 & 0.028 & -0.266 & 0.208 & -0.023 & -0.043 & 0.184 & -0.004 \\
\hline English Proficient & 0.017 & 0.101 & 0.003 & -0.017 & 0.119 & -0.001 & -0.028 & 0.131 & -0.003 \\
\hline Years of Experience & -0.018 & 0.022 & -0.003 & 0.027 & 0.027 & 0.002 & 0.007 & 0.026 & 0.001 \\
\hline South & -0.017 & 0.140 & -0.003 & 0.007 & 0.160 & 0.001 & 0.016 & 0.181 & 0.001 \\
\hline West & -0.106 & 0.118 & -0.017 & 0.045 & 0.136 & 0.004 & 0.130 & 0.153 & 0.011 \\
\hline North East & $-0.326 * *$ & 0.148 & -0.060 & $0.379 * *$ & 0.169 & 0.042 & 0.178 & 0.179 & 0.018 \\
\hline Post Legalization & $-0.795 * *$ & 0.377 & -0.127 & 0.388 & 0.532 & 0.034 & 0.871* & 0.449 & 0.081 \\
\hline LPS & $0.714^{* * *}$ & 0.178 & 0.123 & $-0.807 * * *$ & 0.263 & -0.082 & $-0.499 * *$ & 0.208 & -0.048 \\
\hline Education*Post Legalization & 0.021 & 0.022 & 0.003 & 0.012 & 0.028 & 0.001 & -0.037 & 0.027 & -0.003 \\
\hline Years of Experience*Post Legalization & $0.044 *$ & 0.023 & 0.007 & -0.034 & 0.032 & -0.003 & $-0.046^{*}$ & 0.027 & -0.004 \\
\hline Number of Observations & & 2782 & & & 2782 & & & 2782 & \\
\hline Wald Chi2(16) & & 103.45 & & & 56.63 & & & 53.12 & \\
\hline Prob $>$ Chi2 & & 0.000 & & & 0.000 & & & 0.000 & \\
\hline Log Likelihood & & -845.193 & & & -524.050 & & & -515.900 & \\
\hline
\end{tabular}

Notes: *** Signifies statistically different from zero at the 1 percent level or better, **signifies statistically different from zero at the 5 percent level or better and *signifies statistically different from zero at the 10 percent level or better. The regressions include a constant. 


\begin{tabular}{|c|c|c|c|c|c|c|c|c|c|}
\hline \multicolumn{10}{|c|}{$\begin{array}{l}\text { Table 2B } \\
\text { Probit Estimates of the Effect of Legalization on Female Labor Market Outcomes }\end{array}$} \\
\hline \multirow{2}{*}{$\begin{array}{l}\text { Dependent Variable } \\
\text { Independent Variables } \\
\end{array}$} & \multicolumn{3}{|c|}{ Employed } & \multicolumn{3}{|c|}{ Unemployed } & \multicolumn{3}{|c|}{ Not in the Labor Force } \\
\hline & Coeff. & S.E. & M.E. & Coeff. & S.E. & M.E. & Coeff. & S.E. & M.E. \\
\hline Age & -0.008 & 0.014 & -0.003 & 0.003 & 0.019 & 0.000 & 0.007 & 0.014 & 0.002 \\
\hline Married & -0.107 & 0.068 & -0.037 & $-0.231 * *$ & 0.096 & -0.025 & $0.214^{* * *}$ & 0.069 & 0.066 \\
\hline Family Size & $-0.099 * * *$ & 0.018 & -0.035 & 0.030 & 0.025 & 0.003 & $0.099 * * *$ & 0.017 & 0.031 \\
\hline Mexican & -0.021 & 0.071 & -0.007 & $0.217^{* *}$ & 0.105 & 0.022 & -0.049 & 0.072 & -0.015 \\
\hline Education & $0.057 * * *$ & 0.014 & 0.020 & $-0.039 *$ & 0.022 & -0.004 & $-0.052 * * *$ & 0.015 & -0.016 \\
\hline U.S. Education & -0.097 & 0.140 & -0.034 & -0.136 & 0.219 & -0.014 & 0.162 & 0.144 & 0.050 \\
\hline English Proficient & $0.152 *$ & 0.085 & 0.054 & 0.093 & 0.138 & 0.009 & $-0.203^{* *}$ & 0.092 & -0.065 \\
\hline Years of Experience & 0.020 & 0.015 & 0.007 & 0.004 & 0.021 & 0.000 & -0.023 & 0.015 & -0.007 \\
\hline South & $0.185^{*}$ & 0.107 & 0.062 & -0.160 & 0.148 & -0.015 & -0.151 & 0.113 & -0.046 \\
\hline West & 0.040 & 0.093 & 0.014 & -0.016 & 0.129 & -0.002 & -0.041 & 0.098 & -0.013 \\
\hline North East & -0.181 & 0.130 & -0.065 & 0.261 & 0.183 & 0.032 & 0.105 & 0.136 & 0.034 \\
\hline Post Legalization & -0.029 & 0.285 & -0.010 & -0.315 & 0.430 & -0.033 & 0.128 & 0.300 & 0.040 \\
\hline LPS & $0.446 * * *$ & 0.154 & 0.154 & $-0.427^{*}$ & 0.243 & -0.044 & $-0.362 * *$ & 0.159 & -0.112 \\
\hline LPS*Post Legalization & $-0.298 * *$ & 0.117 & -0.107 & 0.291 & 0.208 & 0.034 & $0.244 * *$ & 0.123 & $\mathbf{0 . 0 8 0}$ \\
\hline Education*Post Legalization & -0.023 & 0.016 & -0.008 & 0.042 & 0.028 & 0.004 & 0.011 & 0.017 & 0.003 \\
\hline Years of Experience*Post Legalization & 0.025 & 0.017 & 0.009 & -0.011 & 0.027 & -0.001 & -0.023 & 0.018 & -0.007 \\
\hline Number of Observations & & 2333 & & & 2333 & & & 2333 & \\
\hline Wald Chi2(16) & & 120.35 & & & 120.35 & & & 123.77 & \\
\hline Prob > Chi2 & & 0.000 & & & 0.000 & & & 0.000 & \\
\hline
\end{tabular}

Notes: *** Signifies statistically different from zero at the 1 percent level or better, **signifies statistically different from zero at the 5 percent level or better and *signifies statistically different from zero at the 10 percent level or better. The regressions include a constant. The regional reference category is North Central. 


\begin{tabular}{|c|c|c|c|c|c|c|c|c|c|c|c|c|}
\hline \multicolumn{13}{|c|}{$\begin{array}{l}\text { Table 3A } \\
\text { The Role of Returns to Human Capital as Determinants of Male Employment and Unemployment Statuses }\end{array}$} \\
\hline \multirow{4}{*}{ Independent Variables } & \multicolumn{6}{|c|}{$\begin{array}{ll}\text { LPS } \\
\end{array}$} & \multicolumn{6}{|c|}{ NLSY79 } \\
\hline & \multicolumn{3}{|c|}{1987} & \multicolumn{3}{|c|}{1992} & \multicolumn{3}{|c|}{1987} & \multicolumn{3}{|c|}{1992} \\
\hline & Coeff. & S.E. & M.E. & Coeff. & S.E. & M.E. & Coeff. & S.E. & M.E. & Coeff. & S.E. & M.E. \\
\hline & \multicolumn{12}{|c|}{ Employed } \\
\hline English Proficient & -0.145 & 0.203 & -0.012 & 0.176 & 0.126 & 0.031 & - & - & - & - & - & - \\
\hline U.S. Education & 0.333 & 0.280 & 0.022 & 0.188 & 0.197 & 0.030 & - & - & - & - & - & - \\
\hline Education & -0.046 & 0.027 & -0.004 & -0.009 & 0.016 & -0.002 & $0.080 * * *$ & 0.032 & 0.018 & $0.111 * * *$ & 0.032 & 0.028 \\
\hline Years of Experience & -0.017 & 0.039 & -0.001 & 0.040 & 0.032 & 0.007 & $-1.37 e-04$ & 0.029 & $-3.1 e-05$ & 0.026 & 0.024 & 0.007 \\
\hline Number of Observations & & 759 & & & 804 & & & 557 & & & 592 & \\
\hline \multicolumn{13}{|l|}{ Regression Fit Statistics } \\
\hline LR Chi2(10) & & 8.52 & & & 12.27 & & & 38.89 & & & 62.55 & \\
\hline \multirow[t]{2}{*}{ Prob > Chi2 } & & 0.578 & & & 0.344 & & & 0.000 & & & 0.000 & \\
\hline & \multicolumn{12}{|c|}{ Unemployed } \\
\hline English Proficient & 0.242 & 0.281 & 0.008 & -0.164 & 0.146 & -0.019 & - & - & - & - & - & - \\
\hline U.S. Education & -0.170 & 0.407 & -0.005 & -0.305 & 0.248 & -0.031 & - & - & - & - & - & - \\
\hline Education & 0.011 & 0.037 & $3.68 \mathrm{e}-04$ & -0.002 & 0.019 & $2.32 \mathrm{e}-04$ & -0.070 & 0.044 & -0.006 & -0.042 & 0.036 & -0.005 \\
\hline Years of Experience & 0.029 & 0.054 & $9.56 \mathrm{e}-04$ & -0.015 & 0.037 & -0.002 & 0.034 & 0.040 & 0.003 & -0.008 & 0.029 & -0.001 \\
\hline Number of Observations & & 759 & & & 804 & & & 557 & & & 535 & \\
\hline \multicolumn{13}{|l|}{ Regression Fit Statistics } \\
\hline LR Chi2(10) & & 6.12 & & & 7.92 & & & 25.60 & & & 592 & \\
\hline Prob > Chi2 & & 0.805 & & & 0.721 & & & 0.002 & & & 0.001 & \\
\hline
\end{tabular}

Notes: ${ }^{* * *}$ Signifies statistically different from zero at the 1 percent level or better, ${ }^{* *}$ signifies statistically different from zero at the 5 percent level or better and *signifies statistically different from zero at the 10 percent level or better. The regressions include a constant, information on respondents' age, marital status, family size, Mexican ethnicity and region of residence in the U.S. 


\begin{tabular}{|c|c|c|c|c|c|c|c|c|c|c|c|c|}
\hline \multicolumn{13}{|c|}{$\begin{array}{l}\text { Table 3B } \\
\text { The Role of Returns to Human Capital as Determinants of Female Employment and Unemployment Statuses }\end{array}$} \\
\hline \multirow{4}{*}{ Independent Variables } & \multicolumn{6}{|c|}{ LPS } & \multicolumn{6}{|c|}{ NLSY79 } \\
\hline & \multicolumn{3}{|c|}{1987} & \multicolumn{3}{|c|}{1992} & \multicolumn{3}{|c|}{1987} & \multicolumn{3}{|c|}{1992} \\
\hline & Coeff. & S.E. & M.E. & Coeff. & S.E. & M.E. & Coeff. & S.E. & M.E. & Coeff. & S.E. & M.E. \\
\hline & \multicolumn{12}{|c|}{ Employed } \\
\hline English Proficient & 0.124 & 0.133 & 0.039 & $0.276 * *$ & 0.124 & 0.098 & - & - & - & - & - & - \\
\hline U.S. Education & -0.112 & 0.186 & -0.039 & 0.015 & 0.175 & 0.006 & - & - & - & - & - & - \\
\hline Education & $0.038 * *$ & 0.019 & 0.012 & 0.004 & 0.016 & 0.002 & $0.094^{* * *}$ & 0.029 & 0.037 & $0.103^{* * *}$ & 0.027 & 0.041 \\
\hline Years of Experience & 0.015 & 0.023 & 0.005 & 0.002 & 0.024 & 0.001 & 0.016 & 0.022 & 0.007 & $0.068 * * *$ & 0.018 & 0.027 \\
\hline Number of Observations & & 593 & & & 544 & & & 585 & & & 611 & \\
\hline \multicolumn{13}{|l|}{ Regression Fit Statistics } \\
\hline LR Chi2(11) & & 49.10 & & & 24,68 & & & 44.37 & & & 51,71 & \\
\hline Prob > Chi2 & & 0.000 & & & 0.010 & & & 0.000 & & & 0.000 & \\
\hline & \multicolumn{12}{|c|}{ Not in the Labor Force } \\
\hline English Proficient & -0.147 & 0.139 & -0.042 & $-0.347^{* * *}$ & 0.130 & -0.112 & - & - & - & - & - & - \\
\hline U.S. Education & 0.151 & 0.192 & 0.045 & 0.087 & 0.181 & 0.030 & - & - & - & - & - & - \\
\hline Education & -0.023 & 0.019 & -0.007 & -0.008 & 0.017 & -0.003 & $-0.082^{* *}$ & 0.030 & -0.032 & $-0.1188^{* * *}$ & 0.029 & -0.046 \\
\hline Years of Experience & -0.011 & 0.023 & -0.003 & -0.002 & 0.024 & -0.001 & -0.026 & 0.023 & -0.010 & $-0.065^{* * *}$ & 0.019 & -0.026 \\
\hline Number of Observations & & 593 & & & 544 & & & 585 & & & 611 & \\
\hline \multicolumn{13}{|l|}{ Regression Fit Statistics } \\
\hline LR Chi2(20) & & 51,25 & & & 30.62 & & & 35.45 & & & 56.67 & \\
\hline Prob > Chi2 & & 0.000 & & & 0.001 & & & 0.000 & & & 0.000 & \\
\hline
\end{tabular}

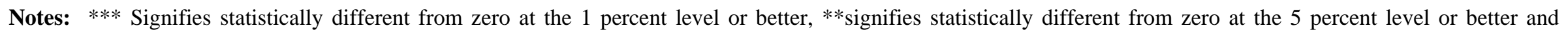

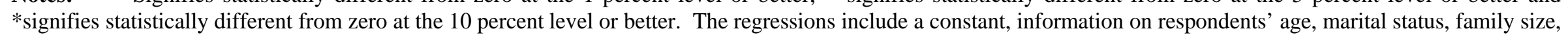
Mexican ethnicity and region of residence in the U.S. 


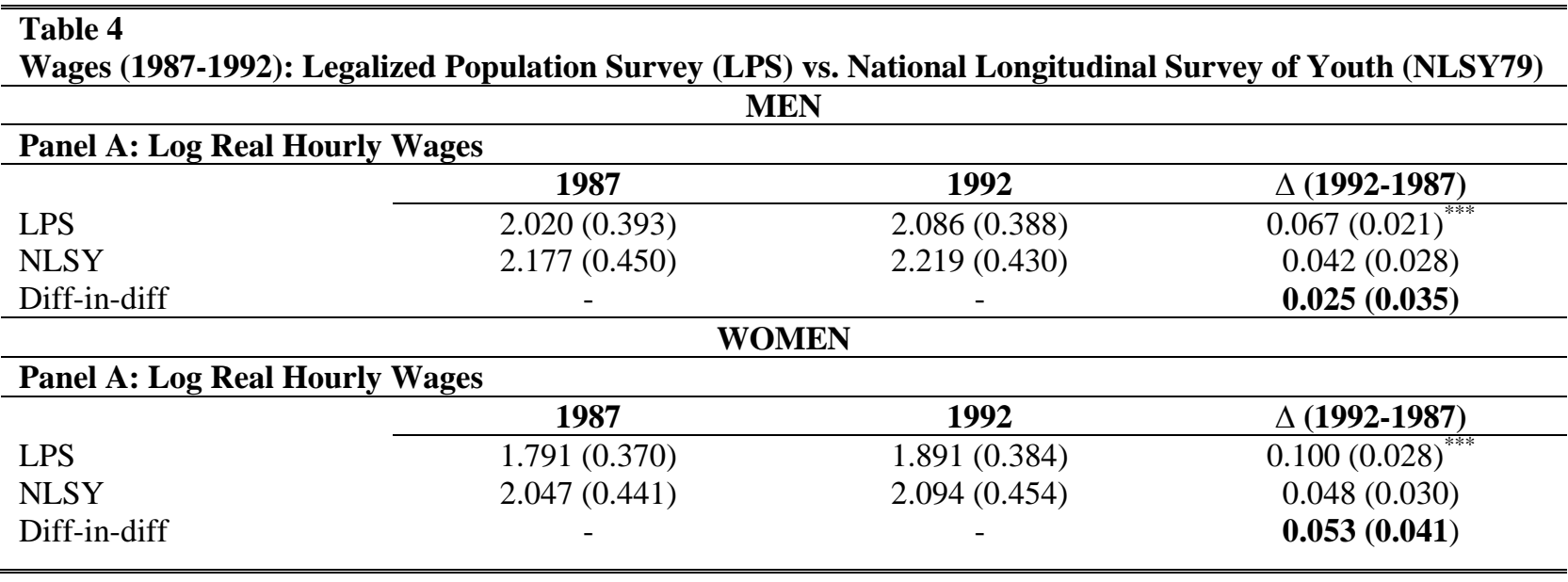

Notes: Standard errors are in parentheses. ${ }^{* * *}$ Signifies statistically different from zero at the 1 percent level or better, ${ }^{* *}$ signifies statistically different from zero at the 5 percent level or better and ${ }^{*}$ signifies statistically different from zero at the 10 percent level or better. 


\begin{tabular}{|c|c|c|c|c|}
\hline \multicolumn{5}{|c|}{$\begin{array}{l}\text { Table } 5 \\
\text { Wage Growth Estimates for Respondents Working in } 1987 \text { and in } 1992\end{array}$} \\
\hline \multirow{2}{*}{ Group } & \multicolumn{2}{|c|}{ MEN } & \multicolumn{2}{|c|}{ WOMEN } \\
\hline & Coefficient & S.E. & Coefficient & S.E. \\
\hline Age & -0.009 & 0.007 & -0.010 & 0.009 \\
\hline Mexican & 0.015 & 0.028 & -0.046 & 0.038 \\
\hline Education & -0.001 & 0.004 & 0.006 & 0.006 \\
\hline U.S. Education & 0.023 & 0.052 & 0.074 & 0.082 \\
\hline English Proficient & $0.054 *$ & 0.034 & 0.026 & 0.051 \\
\hline Years of Experience & -0.003 & 0.005 & -0.004 & 0.008 \\
\hline Agriculture \& Mining & -0.048 & 0.060 & -0.075 & 0.145 \\
\hline Construction & 0.019 & 0.044 & -0.250 & 0.323 \\
\hline Manufacturing & 0.014 & 0.033 & 0.010 & 0.050 \\
\hline TCPU & 0.056 & 0.054 & 0.067 & 0.107 \\
\hline FIRE & -0.007 & 0.083 & 0.024 & 0.076 \\
\hline Business Services & 0.076 & 0.054 & -0.033 & 0.080 \\
\hline Personal Services & $-0.143 * *$ & 0.074 & -0.001 & 0.066 \\
\hline Recreational Services & -0.035 & 0.132 & $-0.245^{* *}$ & 0.106 \\
\hline Professional Services & $0.137 * *$ & 0.059 & 0.043 & 0.057 \\
\hline Public Administration & 0.049 & 0.069 & $0.205^{* *}$ & 0.093 \\
\hline South & -0.052 & 0.041 & $0.090^{*}$ & 0.051 \\
\hline West & -0.006 & 0.032 & 0.032 & 0.042 \\
\hline North East & 0.002 & 0.061 & 0.005 & 0.070 \\
\hline LPS & $0.104 * *$ & 0.053 & $0.189 * *$ & 0.089 \\
\hline Number of Observations & 923 & & 521 & \\
\hline \multicolumn{5}{|l|}{ Regression Fit Statistics } \\
\hline F(20, Number of Observations) & \multicolumn{2}{|c|}{1.47} & \multicolumn{2}{|c|}{1.45} \\
\hline Prob $>F$ & \multicolumn{2}{|c|}{0.082} & \multicolumn{2}{|c|}{0.093} \\
\hline
\end{tabular}

Notes: $* * *$ Signifies statistically different from zero at the 1 percent level or better, ${ }^{* *}$ signifies statistically different from zero at the 5 percent level or better and *signifies statistically different from zero at the 10 percent level or better. The regressions include a constant. North Central and Wholesale and Retail Trade are used as reference. 


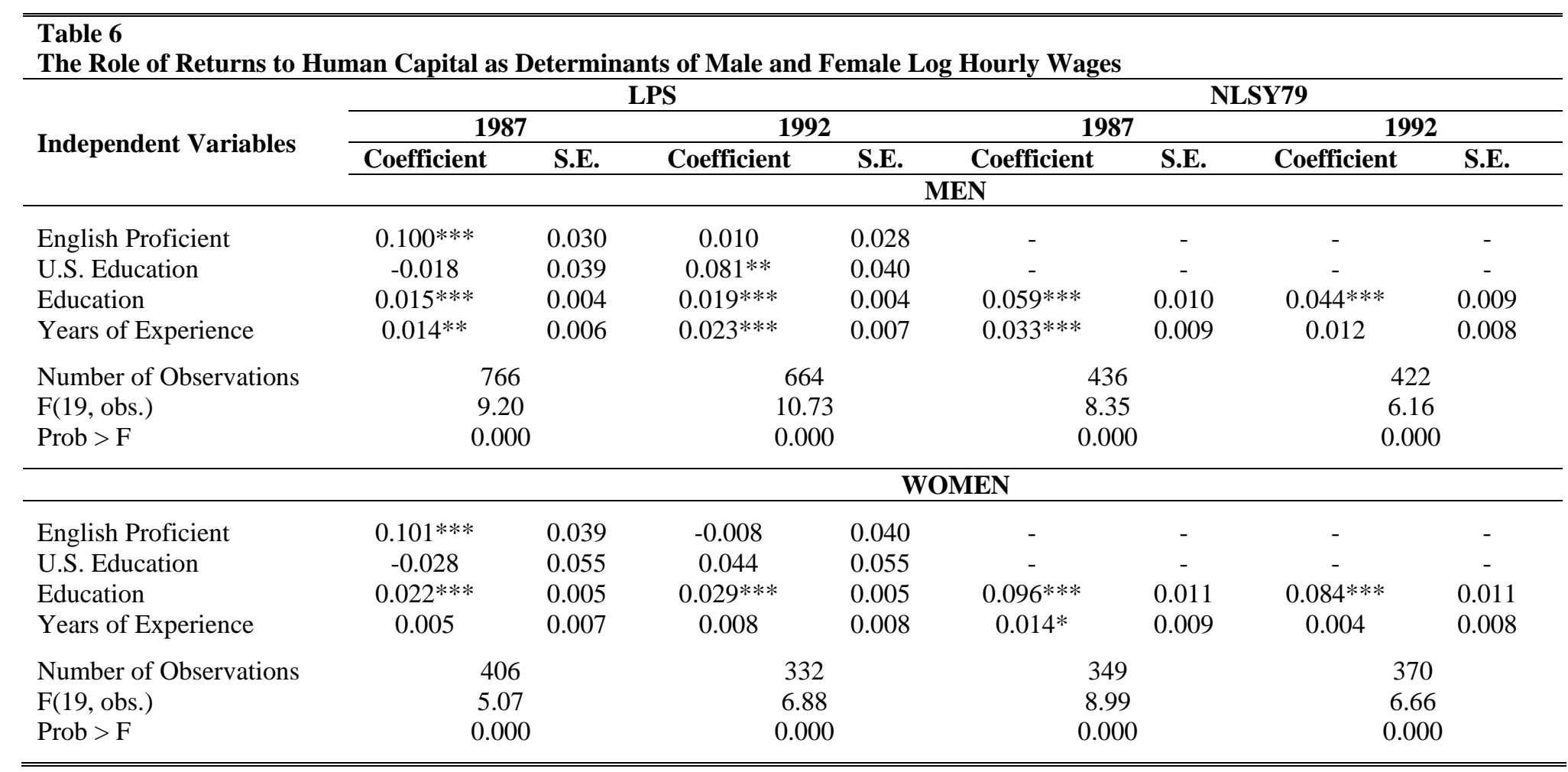

Notes: *** Signifies statistically different from zero at the 1 percent level or better, ** signifies statistically different from zero at the 5 percent level or better and *signifies statistically different from zero at the 10 percent level or better. The employment and wage equations include a constant, information on respondents' age, Mexican ethnicity and region of residence in the U.S. The main equation also includes information on the industry of employment. For identification purposes, only the employment selection equation includes information on marital status and family size. 


\section{Appendix Tables}

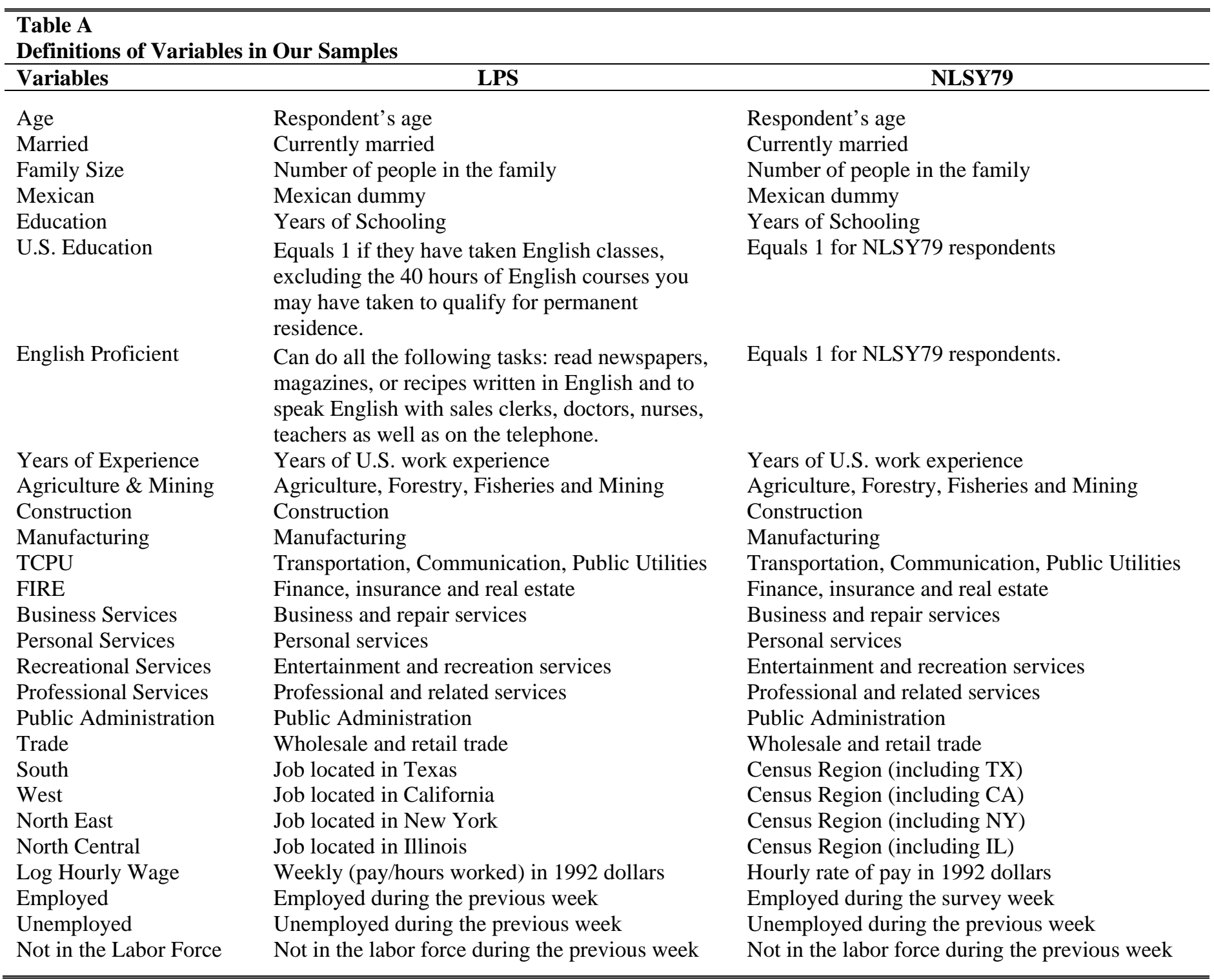




\begin{tabular}{|c|c|c|c|c|c|c|c|c|}
\hline \multicolumn{9}{|c|}{$\begin{array}{l}\text { Table B } \\
\text { Male Means and Standard Deviations }\end{array}$} \\
\hline \multirow{3}{*}{$\begin{array}{l}\text { Sample } \\
\text { Time Periods } \\
\text { Descriptive Statistic } \\
\end{array}$} & \multicolumn{4}{|c|}{ LPS } & \multicolumn{4}{|c|}{ NLSY79 } \\
\hline & \multicolumn{2}{|c|}{ Pre-Legalization } & \multicolumn{2}{|c|}{ Post-Legalization } & \multicolumn{2}{|c|}{ Pre-Legalization } & \multicolumn{2}{|c|}{ Post-Legalization } \\
\hline & Mean & S.D. & Mean & S.D. & Mean & S.D. & Mean & S.D. \\
\hline \multicolumn{9}{|l|}{ For All Respondents: } \\
\hline Age & 26.69 & 2.25 & 31.69 & 2.25 & 26.81 & 2.19 & 30.75 & 2.19 \\
\hline Married & 0.59 & 0.49 & 0.76 & 0.42 & 0.45 & 0.50 & 0.53 & 0.50 \\
\hline Family Size & 3.49 & 2.06 & 4.27 & 2.30 & 3.25 & 1.92 & 3.31 & 1.72 \\
\hline Mexican & 0.57 & 0.50 & 0.57 & 0.50 & 0.57 & 0.50 & 0.57 & 0.50 \\
\hline Education & 9.15 & 3.89 & 9.65 & 4.37 & 12.09 & 2.19 & 12.27 & 2.34 \\
\hline U.S. Education & 0.14 & 0.34 & 0.14 & 0.34 & 1.00 & 0.00 & 1.00 & 0.00 \\
\hline English Proficient & 0.58 & 0.49 & 0.45 & 0.50 & 1.00 & 0.00 & 1.00 & 0.00 \\
\hline Years of Experience & 7.29 & 2.27 & 12.29 & 2.27 & 7.47 & 2.77 & 11.47 & 2.77 \\
\hline South & 0.13 & 0.33 & 0.13 & 0.33 & 0.32 & 0.47 & 0.32 & 0.47 \\
\hline West & 0.57 & 0.50 & 0.56 & 0.50 & 0.46 & 0.50 & 0.46 & 0.50 \\
\hline North East & 0.08 & 0.27 & 0.07 & 0.26 & 0.16 & 0.37 & 0.16 & 0.37 \\
\hline North Central & 0.07 & 0.26 & 0.08 & 0.27 & 0.06 & 0.24 & 0.06 & 0.24 \\
\hline Employed & 0.96 & 0.19 & 0.89 & 0.31 & 0.87 & 0.34 & 0.85 & 0.36 \\
\hline Unemployed & 0.01 & 0.12 & 0.07 & 0.25 & 0.06 & 0.23 & 0.08 & 0.27 \\
\hline Not in the Labor Force & 0.02 & 0.15 & 0.04 & 0.20 & 0.07 & 0.26 & 0.07 & 0.26 \\
\hline \multicolumn{9}{|c|}{ For Working Respondents: } \\
\hline Log Hourly Wage & 2.00 & 0.37 & 2.09 & 0.38 & 2.19 & 0.44 & 2.23 & 0.43 \\
\hline Agriculture \& Mining & 0.06 & 0.24 & 0.06 & 0.23 & 0.04 & 0.20 & 0.05 & 0.23 \\
\hline Construction & 0.13 & 0.34 & 0.13 & 0.33 & 0.09 & 0.29 & 0.09 & 0.28 \\
\hline Manufacturing & 0.30 & 0.46 & 0.25 & 0.43 & 0.23 & 0.42 & 0.23 & 0.42 \\
\hline TCPU & 0.03 & 0.18 & 0.05 & 0.23 & 0.10 & 0.30 & 0.10 & 0.30 \\
\hline FIRE & 0.02 & 0.14 & 0.02 & 0.12 & 0.03 & 0.18 & 0.03 & 0.16 \\
\hline Business Services & 0.09 & 0.29 & 0.09 & 0.29 & 0.10 & 0.30 & 0.10 & 0.30 \\
\hline Personal Services & 0.04 & 0.21 & 0.07 & 0.26 & 0.02 & 0.15 & 0.03 & 0.17 \\
\hline Recreational Services & 0.01 & 0.11 & 0.01 & 0.10 & 0.02 & 0.12 & 0.01 & 0.11 \\
\hline Professional Services & 0.02 & 0.14 & 0.03 & 0.17 & 0.08 & 0.27 & 0.10 & 0.30 \\
\hline Public Administration & 0.00 & 0.04 & 0.01 & 0.08 & 0.07 & 0.25 & 0.09 & 0.28 \\
\hline Trade & 0.29 & 0.46 & 0.29 & 0.45 & 0.22 & 0.42 & 0.19 & 0.39 \\
\hline
\end{tabular}




\begin{tabular}{|c|c|c|c|c|c|c|c|c|}
\hline \multirow{3}{*}{$\begin{array}{l}\text { Sample } \\
\text { Time Periods } \\
\text { Descriptive Statistic } \\
\end{array}$} & \multicolumn{4}{|c|}{ LPS } & \multicolumn{4}{|c|}{ NLSY79 } \\
\hline & \multicolumn{2}{|c|}{ Pre-Legalization } & \multicolumn{2}{|c|}{ Post-Legalization } & \multicolumn{2}{|c|}{ Pre-Legalization } & \multicolumn{2}{|c|}{ Post-Legalization } \\
\hline & Mean & S.D. & Mean & S.D. & Mean & S.D. & Mean & S.D. \\
\hline \multicolumn{9}{|l|}{ For All Respondents: } \\
\hline Age & 27.04 & 2.17 & 32.04 & 2.17 & 26.81 & 2.27 & 30.75 & 2.28 \\
\hline Married & 0.66 & 0.47 & 0.76 & 0.43 & 0.53 & 0.50 & 0.56 & 0.50 \\
\hline Family Size & 3.87 & 1.89 & 4.49 & 1.97 & 3.51 & 1.77 & 3.61 & 1.66 \\
\hline Mexican & 0.51 & 0.50 & 0.51 & 0.50 & 0.57 & 0.50 & 0.57 & 0.50 \\
\hline Education & 8.70 & 3.81 & 9.26 & 4.15 & 12.43 & 2.03 & 12.63 & 2.14 \\
\hline U.S. Education & 0.12 & 0.33 & 0.12 & 0.33 & 1.00 & 0.00 & 1.00 & 0.00 \\
\hline English Proficient & 0.48 & 0.50 & 0.37 & 0.48 & 1.00 & 0.00 & 1.00 & 0.00 \\
\hline Years of Experience & 6.88 & 2.54 & 11.88 & 2.54 & 7.26 & 2.91 & 11.26 & 2.91 \\
\hline South & 0.14 & 0.34 & 0.13 & 0.34 & 0.32 & 0.47 & 0.33 & 0.47 \\
\hline West & 0.59 & 0.49 & 0.59 & 0.49 & 0.43 & 0.49 & 0.42 & 0.49 \\
\hline North East & 0.08 & 0.26 & 0.07 & 0.26 & 0.17 & 0.37 & 0.16 & 0.36 \\
\hline North Central & 0.08 & 0.27 & 0.07 & 0.26 & 0.09 & 0.29 & 0.09 & 0.29 \\
\hline Employed & 0.73 & 0.44 & 0.66 & 0.47 & 0.69 & 0.46 & 0.69 & 0.46 \\
\hline Unemployed & 0.04 & 0.19 & 0.06 & 0.24 & 0.06 & 0.23 & 0.07 & 0.26 \\
\hline Not in the Labor Force & 0.23 & 0.42 & 0.28 & 0.45 & 0.26 & 0.44 & 0.23 & 0.42 \\
\hline \multicolumn{9}{|c|}{ For Working Respondents: } \\
\hline Log Hourly Wage & 1.78 & 0.36 & 1.92 & 0.39 & 2.10 & 0.43 & 2.18 & 0.42 \\
\hline Agriculture \& Mining & 0.01 & 0.09 & 0.01 & 0.11 & 0.03 & 0.16 & 0.02 & 0.14 \\
\hline Construction & 0.00 & 0.00 & 0.00 & 0.00 & 0.01 & 0.10 & 0.01 & 0.08 \\
\hline Manufacturing & 0.31 & 0.46 & 0.26 & 0.44 & 0.10 & 0.30 & 0.12 & 0.33 \\
\hline TCPU & 0.02 & 0.13 & 0.02 & 0.13 & 0.05 & 0.21 & 0.06 & 0.24 \\
\hline FIRE & 0.02 & 0.14 & 0.04 & 0.19 & 0.14 & 0.35 & 0.14 & 0.35 \\
\hline Business Services & 0.06 & 0.24 & 0.03 & 0.17 & 0.04 & 0.20 & 0.04 & 0.19 \\
\hline Personal Services & 0.26 & 0.44 & 0.23 & 0.42 & 0.03 & 0.16 & 0.04 & 0.20 \\
\hline Recreational Services & 0.02 & 0.13 & 0.01 & 0.11 & 0.02 & 0.14 & 0.01 & 0.11 \\
\hline Professional Services & 0.10 & 0.30 & 0.14 & 0.35 & 0.28 & 0.45 & 0.32 & 0.47 \\
\hline Public Administration & 0.00 & 0.00 & 0.01 & 0.09 & 0.11 & 0.31 & 0.05 & 0.22 \\
\hline Trade & 0.21 & 0.41 & 0.26 & 0.44 & 0.21 & 0.41 & 0.18 & 0.39 \\
\hline
\end{tabular}




\section{Illustration of the Impact of Legalization on Employment}

\section{Figure A: Remaining Employed}

Disposable Income

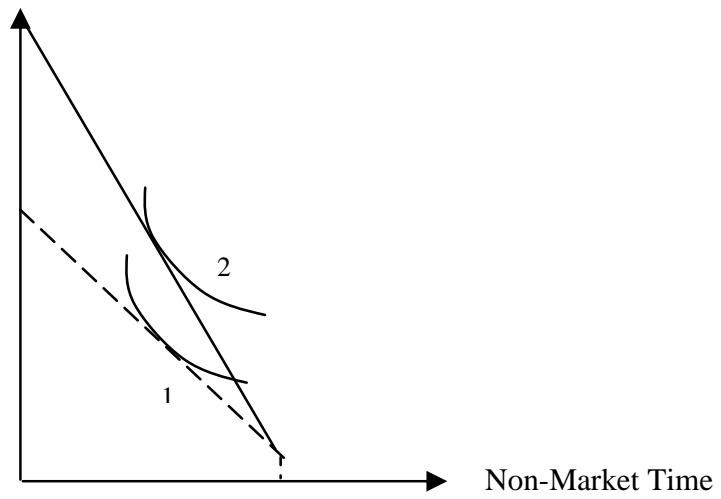

Figure B: Unemployment - UI

Figure B: Unemployment -- AFDC

Disposable Income

Disposable Income
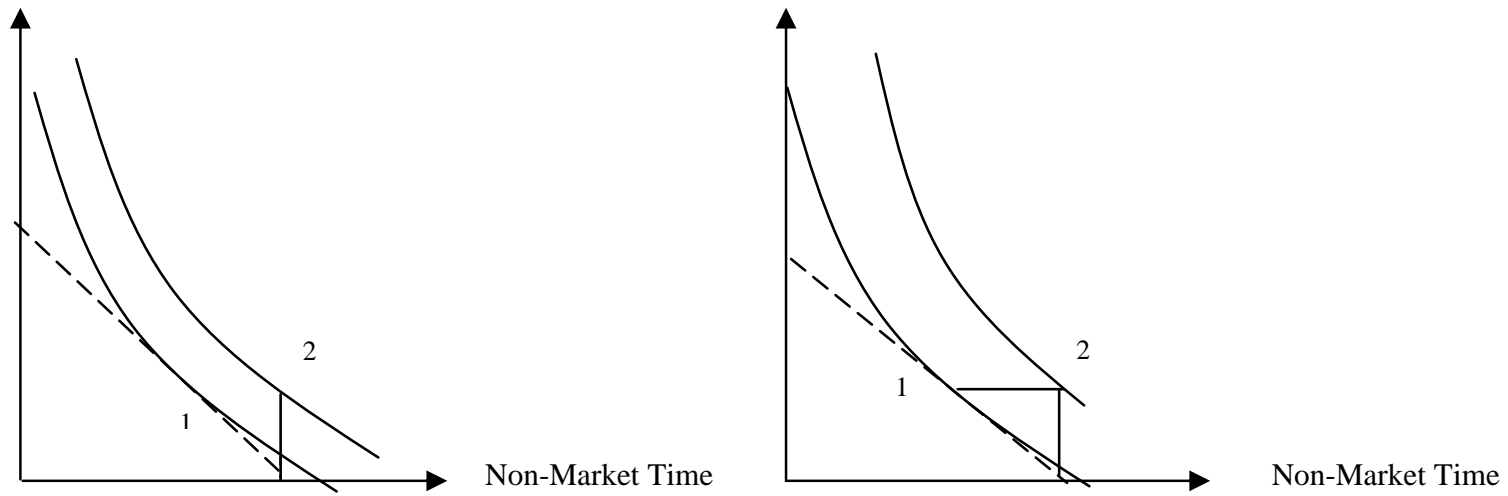

Note: Dotted lines represent the budget constraint prior to Legalization. Solid lines represent the budget constraint post Legalization.

Figure C: Becoming Employed

Disposable Income

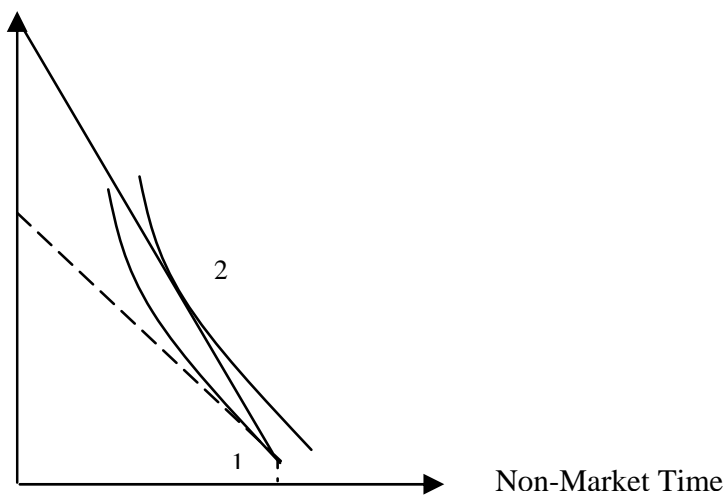

Note: Dotted lines represent the budget constraint prior to Legalization. Solid lines represent the budget constraint post Legalization. 